УДК 340

\author{
Катерина Андріївна Шуневич, \\ юридичний факультет \\ Львівського національного університету \\ імені Івана Франка
}

\title{
ПРАВО НА СПРАВЕДЛИВИЙ СУД ПРИ ОРГАНІЗАЦІЇ ТА ПРОВЕДЕННІ СУДОВОЇ ЕКСПЕРТИЗИ
}

Постановка проблеми. Відповідно до тлумачення Європейського суду з прав людини (далі ЄСПЛ) право на справедливий суд $€$ основою принципу верховенства права в демократичному суспільстві та спрямований на належне і справедливе здійснення правосуддя. При цьому, як зазначає Н. Бобечко, справедливість має фундаментальний характер для кримінального провадження: вона охоплює правовий ідеал належного кримінального судочинства та суспільний запит на встановлення істини. Справедливість $є$ передумовою будь-якої процесуальної дії, рішення, вихідним моментом правильного розуміння та застосування закону [1, с. 2].

Експертне забезпечення кримінального провадження шляхом залучення фахівців зі спеціальними знаннями - судових експертів - $є$ надзвичайно важливим для правильного вирішення кримінального провадження та - в результаті - реальної дії права на справедливий суд, гарантованого ст. 6 Конвенції про захист прав людини та основоположних свобод (далі - СКПЛ). Як зазначає А. Омельченко, використання експертиз у судовому провадженні $є$ надзвичайно актуальним питанням, зважаючи на те, що одним із головних завдань судочинства $є$ забезпечення рівності всіх учасників судового процесу, у тому числі і стосовно надання суду належних доказів [2, с. 41-43]. Отож, актуальність даної тематики зумовлена потребою вироблення грунтовних теоретичних напрацювань у заданій проблематиці, а також важливим процесуальним значенням висновку експерта як доказу в судовому провадженні.

Дослідження окремих аспектів вищезазначеної проблематики було здійснено такими вченими зарубіжної та національної кримінально-процесуальної доктрини, як Авдєєва Г., Альохін Н., Ліанза П., Прідаль О., Вавринчук Т., Малахова О., Ткачук О., Матат Ю., Трегубов Е., Бучик А., Ратушна Б., Фулей Т., Калужна О., Клименко Н., Сімакова-Сфремян Е., Пилипенко Г., Олійник О., Романенко Л., Калинюк Н., Цоколова О. та інші.

Основною метою даної наукової роботи $є$ аналіз ключових елементів права на справедливий суд, що мають безпосереднє значення при організації та проведенні судової експертизи, національного законодавства, а також практики ЄСПЛ, у якій Суд сформував правила здійснення судового провадження, які прямо чи побічно стосуються проведення судової експертизи в контексті забезпечення права на справедливий суд.

При написанні даної статті був використаний діалектичний концептуальний підхід пізнання процесів та явищ реальної дійсності і застосовані наступні загальнонаукові та спеціально-юридичні методи пізнання: аналіз, синтез, узагальнення, структурно-функціональний, герменевтико-правовий, порівняльно-правовий методи.

Основні результати дослідження. У Конституції України та процесуальних кодексах відсутнє законодавче буквально-текстуальне закріплення права на справедливий суд, однак шляхом застосування системного аналізу спостерігаємо складові його елементи (верховенство права, законність, рівність перед законом і судом, доступ до правосуддя та ін.). До слова, доречність такого бук- 
вально-текстуального дублювання «права на справедливий суд» у внутрішньому національному законодавстві (імплементації) навряд чи $є$ нагальною в світлі ст. 9 Конституції України: «чинні міжнародні договори, згода на обов'язковість яких надана Верховною Радою України, $є$ частиною національного законодавства України». Отже, стаття 6 ЄКПЛ, яка закріплює право на справедливий суд, повинна прямо застосовуватися, зокрема, ст.19 ЗУ «Про міжнародні договори», відповідно до якої чинні ратифіковані міжнародні договори $є$ частиною національного законодавства і застосовуються у порядку, передбаченому для норм національного законодавства [3].

Водночас у новій редакції від 5.08.2018p. ЗУ «Про судоустрій та статус суддів» в Преамбулі зазначено, що «цей Закон визначає організацію судової влади та здійснення правосуддя в Україні, що функціонує на засадах верховенства права відповідно до європейських стандартів і забезпечує право кожного на справедливий суд» [4]. Стаття 7 зазначеного закону закріплює право на справедливий суд, розкриваючи його через такі категорії, як «розумні строки», «незалежний, безсторонній і справедливий суд, утворений законом».

Варто наголосити, що забезпечення права на справедливий суд відіграє важливу роль в утвердженні прав людини і громадянина, а тому, відповідно, надзвичайно актуальним залишається питання судово-експертного забезпечення правосуддя в контексті європейської інтеграції та реформування системи судоустрою в Україні.

Забезпечення справедливого судового розгляду доволі часто неможливе без проведення судової експертизи та використання висновку експерта як доказу у конкретній справі, можливості його ефективного та належного дослідження. Так, у справі «Красуля проти Російської Федерації»[5] було встановлено, що порушено право на справедливий суд, оскільки суд першої інстанції відмовив заявнику у прийнятті висновку лінгвістичної експертизи як доказу у справі, а в подальшому касаційний суд проігнорував наявність цього доказу та не надав відповідей на доводи заявника, що містились у касаційній скарзі, щодо незаконності такої відмови суду нижчого рівня.

У справі «Мантованеллі проти Франції» $[6, \S 33]$ Суд зазначає, що одним з елементів справедливого судового розгляду $є$ право на змагальний судовий розгляд, одним 3 положень якого $є$ можливість для сторін не лише повідомити та надати будь-які докази, аби суд задовольнив вимоги зазначеної сторони, а й коментувати подані іншою стороною докази та зауваження; так, навіть у випадку, коли експерт призначається судом, сторони повинні мати змогу брати участь у допиті експерта або дослідженні документів, поданих експертом. У справі «Балсіте-Лідекієнє проти Литви» зазначається, що «..висновки, надані експертами на досудовому етапі, мали ключове місце у провадженні проти заявника. Тому необхідно визначити, чи заявник висловив побажання розглянути результати експертизи на відкритому судовому засіданні, і якщо так, то чи є у нього така можливість» [7, § 63-64].

ЄСПЛ у справах «Аккоч проти Туреччини» (§55) і «Барабанщиков проти Російської Федерації» (§59) наголошує на необхідності забезпечення Державами, окрім належної спеціальної підготовки, як формальну, так і фактичну незалежність експертів.

У цьому контексті постає цікаве практичне запитання: чи експерт, що залучається стороною кримінального провадження, повинен надавати об'єктивний та неупереджений висновок в результаті проведення експертного дослідження, чи такий висновок повинен відповідати інтересам сторони, що його залучила. ЄСПЛ у своїх рішеннях зазначає, що відсутність безсторонності експерта, з одного боку, може надати перевагу одній із сторін, а з іншого - зашкодить іншій, порушуючи принцип рівності сторін («Сара Лінд Еггертсдоттір проти Ісландії»).

На нашу думку, оскільки висновок експерта є одним із доказів у справі, а у деяких категоріях справ навіть може мати переважний вплив на оцінку фактів («Івон проти Франції», «Сторк проти Німеччини»), то такий висновок, зважаючи на його природу як результату експертного дослідження шляхом застосування спеціальних знань, у кожному разі повинен бути незалежним та безстороннім незалежно від того, хто є суб'єктом звернення про проведення експертизи. Тоді, якщо сторона залучила експерта для проведення експертизи, останній повинен провести таке дослідження, яке $є$ об'єктивним, безстороннім, а висновок має бути таким, що виключає будь-який сумнів у його достовірності. Якщо ж сторона не задоволена результатами експертного дослідження, то вона може звернутись до іншого експерта з проведенням аналогічної експертизи: такі звернення можуть повторюватись доти, доки певний експерт не надасть такий висновок, який найбільшою мірою міг би задовольняти сторону, що звернулась до експерта про проведення експертизи, при цьому не по- 
рушуючи принципів безсторонності на незалежності експерта при проведенні експертизи. На підтвердження зазначеної позиції можна навести думку О. Малахової, котра вказує, що для сторони захисту, на яку не покладається обов'язок доказування, залучення експерта є ії правом, а, отже, й використання отриманого висновку експерта $є$ іiї правом [8].

На додаток, цікавим $є$ питання щодо дотримання права на справедливий суд у випадку, якщо лише однією зі сторін було залучено експерта для проведення експертизи, а інша такого експерта не залучала, а під час судового розгляду намагалась спростувати достовірність висновку експерта та вимагала призначення незалежної експертизи судом, однак така експертиза не була призначена. Показовим у цьому випадку є справа «Девінар проти Словенії», в котрій заявниця стверджувала, що рішення національних судів щодо неї є несправедливими, бо вони засновані на думках експертів, що були залучені у справу протилежною стороною, а також те, що ій було відмовлено у призначенні незалежного експерта. Однак ЄСПЛ дійшов до висновку, що у даній справі відсутнє порушення ст. 6 ЄКПЛ у рішеннях національних судів, які засновані на висновках фахівців, які призначені лише однією із сторін у справі, а також у відмові призначити незалежного експерта [9, § 35-59].

Незважаючи на те, що у ст. 6 ЄКПЛ нічого не зазначено про інститут судової експертизи, 3-поміж елементів права на справедливий суд, зазначеного у ст. 6 ЄКПЛ, можна виділити такі, на основі яких здійснюється організація проведення судової експертизи в рамках судового провадження. Ці елементи відіграють важливе значення в процесуальному аспекті судової експертизи: тобто безпосередньо стосуються питань залучення експерта. Серед таких визначальних елементів права на справедливий суд, котрі мають зв'язок з інститутом судової експертизи, хочемо виділити наступні: рівність сторін, змагальність сторін і свобода надання доказів, право на захист та принцип правильного вирішення спору і встановлення обгрунтованості кримінального обвинувачення. Нижче розглянемо деякі проблемні питання, пов'язані з цим.

Так, відповідно до змін до КПК України в редакції від 3.10.2017 р. стаття 242 КПК України з'явилась у новій редакції, відповідно до неї експертиза проводитиметься судовим експертом чи експертною установою лише за дорученням слідчого судді чи суду, наданим за клопотанням сторони кримінального провадження або без такого клопотання, за ініціативою цих органів; таким чином, як сторона обвинувачення, так і сторона захисту, наділені «рівним» правом звернутись до уповноваженого суб'єкта - слідчого судді, суду для вирішення питання про призначення експертизи. В результаті, якщо слідчий суддя, суд дійде до висновку, що питання, з якого необхідна експертна думка, $\epsilon$ істотним для кримінального провадження, а також що для його вирішення необхідні спеціальні знання, він самостійно визначає експерта чи експертну установу, яким доручає проведення експертизи.

Також принцип рівності в аспекті досліджуваної проблеми стосується не лише питань рівних прав щодо призначення експертизи, а й пропонування суду питань, котрі необхідно включити в ухвалу про призначення експертизи, можливості допиту експерта у судовому засіданні, можливості заявити клопотання про призначення нової або додаткової експертизи.

Щодо характерних ознак принципу змагальності, то ними виступають наступні: переконання, що протилежність інтересів сторін найкраще забезпечить повноту матеріалів справи через активне виконання сторонами процесу тільки їм притаманних функцій. Принцип змагальності припускає поєднання активності сторін у забезпеченні виконання ними своїх процесуальних обов'язків із забезпеченням судом умов для здійснення наданих їм прав [10].

Так, кожна зі сторін вільна надавати висновки експертів, що підтверджують ії позицію, а суд шляхом безпосереднього дослідження таких висновків експерта та - при потребі - шляхом допиту експерта щодо такого висновку приймає рішення у справі. При цьому суд обмежений у праві призначити судову експертизу, адже вважається, що усі докази, що доводять або спростовують винуватість обвинуваченого, були зібрані на стадії досудового розслідування. Лише у виняткових випадках суд вправі призначити експертизу у країнах Європи: у випадках, якщо необхідне обов'язкове призначення експертизи, однак таку експертизу не було проведено на стадії досудового розслідування, при необхідності проведення додаткової та повторної експертизи.

Принцип змагальності в контексті права сторін бути проінформованим про докази та аргументи іншої сторони, де-факто, означає право на ознайомлення з матеріалами справи, яке може включати право робити фотокопії для ретельного ознайомлення з матеріалами і доказами. Так, Г. Пилипенко вважає, що у КПК необхідно передбачити обов'язок сторони захисту інформувати «протилежну 
сторону», тобто - сторону обвинувачення, про залучення нею експерта та щодо змісту експертного завдання, адже приховування таких висновків звужує обсяг об'єктивних підстав для прийняття судом вірного рішення [11]. Проте, на нашу думку, дане твердження є таким, що прямо суперечить принципу змагальності щодо аспекту вибору сторонами, які докази подавати/не подавати для дослідження судом під час судового розгляду. Проте, слід пам'ятати, що відповідно до вимог КПК України, кожна зі сторін повинна відкрити матеріали іншій стороні, тобто сторона захисту у випадку використання під час судового провадження висновку експерта повинна надати такий процесуальний документ стороні обвинувачення для ознайомлення, при цьому, якщо такий висновок експерта може свідчити про винуватість обвинуваченого у вчиненні кримінального правопорушення, то сторона захисту має право не використовувати такий висновок експерта як доказ у справі та, відповідно, не надавати стороні обвинувачення доступ до таких матеріалів.

Шляхом надання висновків експерта у судове провадження, особистої участі у проведенні експертного дослідження, участі у допиті експерта, надання клопотання до слідчого судді, суду про призначення експертизи сторона кримінального провадження може реалізовувати своє право на захист.

Правильне вирішення спору полягає у тому, що суд на основі безпосереднього дослідження поданих у судове провадження сторонами доказів, що відповідають критеріям допустимості, належності та достовірності, встановлює істину у справі у формі правосудного рішення. Оскільки висновок експерта, який відповідає вимогам, що ставляться до такого документа, $є$ самостійним доказом у справі, то він може бути покладений в основу обвинувачення чи виправдання особи. Проте, як зазначає Н. Клименко, відомості, які містяться у висновку експерта, можуть бути покладені в основу рішення суду лише в сукупності з іншими доказами, які наявні у кримінальній справі [12]. Для того, аби висновок експерта міг бути визнаним доказом у справі, необхідно також зважати на допустимість і належність об’єктів, що надаються для проведення експертизи, адже невідповідність таких об'єктів зазначеним критеріям вестиме до недопустимості висновку експерта як доказу у кримінальному провадженні.

Висновки. Таким чином, елементами права на справедливий суд, передбаченого ст. 6 ЄКПЛ, які відіграють важливу роль при організації та проведенні судової експертизи, виступають такі, як рівність сторін, змагальність сторін і свобода надання доказів, право на захист та принцип правильного вирішення спору і встановлення обгрунтованості кримінального обвинувачення. Право на справедливий суд відіграє вагоме значення при призначенні та проведенні судової експертизи $i$, як наслідок, сприяє забезпеченню прав, свобод та законних інтересів учасників процесу та вирішення справи по суті з постановленням рішення, яке відповідатиме критерію правосудності, тобто буде об'єктивним, неупередженим та справедливим. Здійснення належної судової експертизи може стати на шляху покращення виконання вимог СКПЛ та національного законодавства щодо забезпечення права на справедливий суд і таким чином запобігти порушенню прав учасників судового процесу.

\section{Список використаних джерел}

1. Бобечко Н. Р. Справедливість як цінність кримінального провадження / Н. Р. Бобечко// Часопис Національного університету «Острозька академія». Серія «Право». - 2017. - №1(15) - [Електронний ресурс]. - Режим доступу : http://j.oa.edu.ua/articles/2017/n1/17bnrtkp.pdf

2. Омельченко A. B. Судові та науково-правові експертизи як засіб встановлення доказів згідно з процесуальним законодавством України / А. В. Омельченко // Адвокат. - 2013. - № 5 (152). - С. 41-43.

3. Про міжнародні договори України [Електронний ресурс]. - Закон України від 29.06.2014 p. № 1906-IV. - Режим доступу : http://zakon2.rada.gov.ua/laws/show/1906-15. - Редакція від 20.07.2014

4. Про судоустрій і статус суддів [Електронний ресурс]. - Закон України від 02.06.2016 р.№ 1402-VIII. - Режим доступу: http://zakon.rada.gov.ua/laws/show/1402-19. - Редакція від 05.08.2018.

5. ECHR, Krasulya v. Russia. - 22 February 2017. - Application no. 12365/03 [Електронний ресурс]. - Режим доступу : http://hudoc.echr.coe.int/eng?i=001-126038

6. ECHR, Mantovanelli v France. - 18 March 1997.-Application no. 21497/93 [Електронний ресурс]. - Режим доступу : http://hudoc.echr.coe.int/eng?i=001-58023

7. ECHR, Case of Balsyte-Lideikiene v. Lithuania. - 4 November 2008 - Application no. 72596/01. - [Електронний pecypc]. - Режим доступу : http://hudoc.echr.coe.int/eng?i=001-89307

8. Малахова О. В. Проблемні питання залучення експерта стороною захисту / О. В. Малахова // Право і громадянське суспільство. - 2014. - № 3 (8) [Електронний ресурс]. - Режим доступу : http://lcslaw.knu.ua/ 
9. ECHR, Devinar v. Slovenia. - 22 May 2018 - Application no. 28621/15 [Електронний ресурс]. - Режим доступу : http://hudoc.echr.coe.int/eng?i=001-183127

10. Маркуш М. А. Принцип змагальності в кримінальному процесі України : моногр. - Харків : Видавець СПД ФО Вапнярчук Н. М., 2007. - С. 23-24.

11. Пилипенко Г. М. Ситуації досудового розслідування, що потребують залучення експертів (обізнаних осіб) / Г. М. Пилипенко // Європейські перспективи. - 2013. - № 10. - С. 124-129.

12. Клименко H. I. Структура і доказове значення висновку експерта як документа, що відображує його дослідження / Н. І. Клименко, В. П. Колонюк // Теорія та практика судової експертизи та криміналістики. - 2009. №9. - C. 213-221.

\section{References}

1. Bobechko N. R. Spravedly`vist` yak cinnist` kry`minal`nogo provadzhennya/N.R.Bobechko// Chasopy`s Nacional`nogo universy`tetu «Ostroz`ka akademiya». Seriya «Pravo». - 2017. - \#1(15) -Elektronny`j resurs. - Rezhy`m dostupu:http://lj.oa.edu.ua/articles/2017/n1/17bnrtkp.pdf

2. Omel 'chenko $A$. $V$. Sudovi ta naukovo-pravovi eksperty`zy` yak zasib vstanovlennya dokaziv zgidno z procesual ’ny` $m$ zakonodavstvom Ukrayiny` / A.V. Omel’chenko // Advokat. - 2013. - \# 5 (152). - S. 41-43.

3. Pro mizhnarodni dogovory` Ukrayiny` [Elektronny`j resurs]: Zakon Ukrayiny`vid 29.06.2014 r.\# 1906-IV. - Rezhy`m dostupu : http://zakon2.rada.gov.ua/laws/show/1906-15. - Redakciya vid 20.07.2014.

4. Pro sudoustrij i status suddiv [Elektronny`j resurs]: Zakon Ukrayiny` vid 02.06.2016 r.\# 1402 - VIII. - Rezhy`m dostupu: http://zakon.rada.gov.ua/laws/show/1402-19. - Redakciya vid 05.08.2018.

5. ECHR, Krasulya v. Russia. - 22 February 2017. - Application no. 12365/03 [Elektronny`j resurs]. - Rezhy`m dostupu : http://hudoc.echr.coe.int/eng?i=001-126038

6. ECHR, Mantovanelli v France. - 18 March 1997.- Application no. 21497/93 [Elektronny`j resurs]. - Rezhy`m dostupu : http://hudoc.echr.coe.int/eng?i=001-58023

7. ECHR, Case of Balsyte-Lideikiene v. Lithuania. - 4 November 2008 - Application no. 72596/01 [Elektronny`j resurs]. - Rezhy`m dostupu: http://hudoc.echr.coe.int/eng?i=001-89307

8. Malaxova O. V. Problemni py`tannya zaluchennya eksperta storonoyu zaxy`stu/O. V. Malaxova// Pravo i gromadyans `ke suspil`stvo. - Ky`yiv, 2014. - \# 3 (8) [Elektronny`j resurs]. - Rezhy`m dostupu : http://lcslaw.knu.ua/

9. ECHR, Devinar v. Slovenia. - 22 May 2018 - Application no. 28621/15 [Elektronny`j resurs]. - Rezhy`m dostupu : http://hudoc.echr.coe.int/eng?i=001-183127

10. Markush M. A. Pry`ncy`p zmagal`nosti v kry`minal’nomu procesi Ukrayiny`: monografiya. - Xarkiv : Vy`davecz` SPD FO Vapnyarchuk N.M., 2007. - S. 23-24.

11. Py'ly`penko G. M. Sy`tuaciyi dosudovogo rozsliduvannya, shho potrebuyut'zaluchennya ekspertiv (obiznany`x osib) / G. M. Py`ly`penko // Yevropejs`ki perspekty`vy`. - 2013. - \# 10. - S. 124-129.

12. Kly'menko N. I. Struktura i dokazove znachennya vy'snovku eksperta yak dokumenta, shho vidobrazhuye jogo doslidzhennya / N. I. Kly`menko, V. P. Kolonyuk // Teoriya ta prakty`ka sudovoyi eksperty`zy` ta kry`minalisty`ky”. 2009. - \#9. - S. 213-221.

\section{Шуневич К. А. Право на справедливий суд при організації та проведенні судової експертизи}

У статті аналізуються елементи права на справедливий суд, закріпленого у ст. 6 Конвенції про захист прав людини і основоположних свобод, які відіграють важливу роль при організації та проведенні судової експертизи: рівність сторін, змагальність сторін і свобода надання доказів, право на захист та принцип правильного вирішення спору і встановлення обгрунтованості кримінального обвинувачення. Реальна дія права на справедливий суд виступає ключовою гарантією забезпечення швидкого, повного та неупередженого здійснення судочинства як в кримінальному, так і в цивільному та інших процесах, слугує передумовою правильного вирішення справи та забезпечення виконання завдань, зазначених у процесуальному законодавстві.

Обгрунтовується, що ефективність дотримання права на справедливий суд серед іншого ілюструє процедура організації та проведення судової експертизи, можливість вибирати експерта для проведення експертного дослідження в конкретному кримінальному провадженні, дієвість прав учасників судового провадження щодо можливості брати участь у проведенні експертизи та допиті експерта. Оскільки ефективність організації і проведення судової експертизи є важливим фактором для вирішення справи по суті судом та ухвалення правосудного рішення, наголошується на необхідності імплементації європейських стандартів при регламентації організації та проведення судової експертизи.

Ключові слова: судова експертиза, справедливість, змагальність, рівність сторін, висновок експерта, практика ЄСПЛ. 


\section{Shunevych K. A. The right to a fair trial in organization and conduction of forensic expertise}

Main elements of the right to a fair trial are established by Article 6 of the European Convention on Human Rights. Such provisions as equality of arms, competition between the parties and the freedom to provide evidence, the right to protection, the principle of a proper resolution of a dispute and the establishment of the validity of a criminal prosecution are playing an important role in the organization and conduction of forensic expertise.

The realization of the right to a fair trial is the key guarantee of prompt, full and impartial andministration of justice in both criminal and civil processes. It also ensures the correct resolution of the case and the fulfillment of the tasks, specified in the procedural law.

The right to a fair trial can be considered in two ways. On the one hand, it is possible to appoint a proper forensic expertise, as well as a complete, comprehensive and objective assessment of the expert's opinion and its verification only with the effective realization of the right to a fair trial. On the other hand, the conduct of forensic expertise in a particular court proceeding in accordance with the requirements of the legislation indicates that the principle of ensuring the right to a fair trial is fully implemented in this part.

In the article, the researcher analyzed the practice of the ECHR, in which the Court formed certain rules of court proceedings, that directly or indirectly have relate to the institution of forensic expertise in the context of ensuring the right to a fair trial. ECHR practice proves that the human right to a fair trial is the cornerstone of the rule of law in a democratic society and its goal is the proper and fair administration of justice. Therefore, it is impossible to ensure effective rule of law in the state, where there is the absence of the real exercise of the right to a fair trial.

The author claims that the procedure of the forensic expertise organization, the ability of parties to choose experts in the criminal proceedings, the opportunity of parties to participate in the conduction of forensic expertise and possibility to interrogate experts show the effectiveness of the right to a fair trial.

Since the effectiveness of the organization and conduction of forensic expertise is an important factor in resolving the case by the court, the researcher emphasizes the need to implement European standards of organization of forensic expertise.

Key words: forensic expertise, fairness, adversity, equality of arms, expert opinion, ECHR practice.

DOI: 10.33.66.3/2524-017X-2019-10-359-364 